\title{
THE RELATIONSHIP BETWEEN \\ THE SOCIAL INFRA-STRUCTURE AND THE WORKING OF THE LEGAL SYSTEM: \\ A CASE STUDY ON ACCESS TO JUSTICE IN NORTHERN NIGERIA
}

By M. L. MARASINGHE

\section{Synopsis}

The paper is intended to support the thesis that there exists a relationship between the social infra-structure of a given society and the workings of the legal system which presides over it. In an attempt to examine this relationship a Tribal legal system in the province of Katsina, in Northern Nigeria has been chosen. Out of empirical research conducted in the Native or Tribal Courts in that region, a mass of 1500 decisions were collected and translated into English for use in this and other similar writings. Of this mass of 1500 cases, 300 cases have been chosen for use in this paper. These cases have been categorised into two broad categories. First, those concerned with the "Customary" oaths and the second concerned with Divorce proceedings. These two areas have been singled out for the purposes of this paper for the reason that they both manifest strong cultural underpinnings peculiar to the societies to which they belong. The purpose of the paper is to show the extent to which the infra-structure of a given Tribal society and the workings of the legal system presiding over it maintains a distinct harmony, so that the social and/or Tribal manifestations are reflected to a very large measure in the decisions produced by the Native or Tribal Courts functioning in that society. At the concluding stages of this paper it is intended to show the extent to which the decisions made by the Nigerian Courts adjudicating outside the system of Native Law and Custom departs from the social and cultural underpinnings of the Native or Tribal societies in Nigeria.

At the outset the paper assumes the existence of two systems of laws and two systems for the adjudication of disputes. First, there is the Nigerian Courts modelled upon the English court system and the English legal traditions. This system of Courts primarily apply the "imposed laws", or laws inherited from colonial rule. These laws are primarily derived from the English Common Law and the Statute Laws of the United Kingdom. This total compact forms a "system" for the adjudicatory process in Nigeria. In addition, by virtue of powers given by Section 19 of the Supreme Court Ordinance a) this "system" is provided with a mandate to superintend the workings of the Native or Tribal Courts. Second, the Native or Tribal Court system whose powers are controlled and governed by Section 20 of the Native Court Law, b) provides the "sub-system". The Laws that are applied by this "sub-system" and the process of adjudication adopted by it, are subject to the superintending powers of the Supreme Court of Judicature in Nigeria, which belongs to the "system" described under the first category. The identification and the recognition of a Native Law and Custom "sub-system", subordinated to an "imposed" system borrowed from the English legal system is central to this paper. Within the "sub-system" the position of the "Customary" oath and proceedings concerning Divorce are examined. Regarding the oath, it will be seen, that the "Customary" oath unlike its counterpart in the English legal system is a rule of substantive law. Therefore, the taking of the "Customary" oath would determine such issues as whether the transaction 
was "a loan or a gift" or whether in a particular transaction the parties intended a "mortgage or a sale". These transactions which may in "the system" call for a determination under established rules of law, would in the "sub-system" be determined finally and conclusively by the mere taking of a "Customary" oath. The point shall be made that the psychological commitment of the natives to beliefs in the super-natural coupled with their reliance on superstition, provides a strong basis for the recognition of the "Customary" oath as a sound substitute for a rule of law. Through the affluxion of time, certain rules regarding the application of the "Customary" oath in such disputes as those concerning Immovables, Movables and other matters have begun to emerge. The paper shall consider these categories and state certain rules arising out of an examination of selected decisions in these areas. The conclusion, however, would become clear that the "Customary" oath decides disputes while its counterpart within the Nigerian "system" of imposed laws, shall merely be a matter of procedure providing a pre-condition to the admissibility of evidence.

Under proceedings for the dissolution of marriages the selection of cases will show that marriage in the "sub-system" is merely a question of contract while in the "system" marriage creates a Status. This distinction will underlie the relative approaches taken by the two systems. In will be shown that the "sub-system" recognises the dissolution of marriages by unilateral acts without the concept of fault being imputed to either party to the marriage. Decisions permitting a divorce for such reasons as from: "that the husband had compelled the wife to cut firewood", to a bland declaration that one party had ceased to love the other have been recognised by the "sub-system" as constituting a valid ground for divorces. Further, the "sub-system" permits its courts to be used for the fixing of such obligations as the continuous observance of chastity or Idda for a period of three months after divorce. This has been permitted in cases where the court itself had not pronounced the particular divorce which in fact had been obtained extrajudicially through a Muslim Talaq. In none of these instances would a court in the system of adjudication modelled on the English legal system lend its aid to any litigant. Therefore, the paper will focus on the differences that may be found in the two adjudicatory processes with an eye to emphasising the fact that the "sub-system" alone succeeds in striking a harmony between the infra-structure of the society and the workings of its legal system. The system modelled upon the English legal system fails to achieve that goal and therefore appears to introduce a degree of tension into the Nigerian society. The result, therefore, may be a lack of cohesion between the society and the system of laws and adjudicatory processes which presides over it.

\section{An Introduction}

The focus of this paper is to examine the relationship between a sub-system comprising of Native Law and Custom in four selected areas ${ }^{1}$, in the Province of Katsina, in Northern Nigeria and the particular adjudicative process to which it relates. This adjudicative process may in a general sense be regarded as the "Native Court" system in that country. The Native Court system was recognised, as a forum exclusively for the adjudication of disputes arising between natives, under the various Native Laws and Customs in the Federation of Nigeria. The Native Courts Law ${ }^{2}$ under which the native court system was established in Northern

1 This paper was delivered at the IInd International Congress of Legal Science which was held in Amsterdam, Holland, September 7-12, 1980.

1a Namely; Batsari, Baure, Daura and Funtuwa native areas.

2 Native Courts Law, Law No. 6 of 1956 (Northern Nigeria). 
Nigeria, declared by Section 20 , that a native court shall in civil causes and matters administer:

"(a) the Native Law and Custom prevailing in the area of the jurisdiction of the Court or binding between the parties, so far as it is not repugnant to natural justice, equity and good conscience nor incompatible either directly or by necessary implication with any written law for the time being in force." 3

The use of the term "sub-system" to conceptualize the location of Native Law and Custom within the Nigerian Legal System is justified by the fact that the Native Laws and Customs and the Courts that enforce them are limited in their jurisdiction and in their power to apply substantive rules of native law and custom. The power to superintend these limits is given by statute, ever since the beginnings of Britsh rule in Nigeria, to the "non-native court system" inherited through colonial rule, which was modelled upon the English legal system. The Supreme Court Ordinance of $1863^{4}$ laid down the limits within which the "non-native court system" may regulate the operation of the sub-system concerned, with the administration of Native Law and Custom in Nigeria. The 1863 Ordinance was re-enacted in later years with minor modifications ${ }^{5}$, but each re-enactment left the Ordinance substantively unchanged, and upon the regionalisation of Nigeria, each region adopted ${ }^{6}$ the Supreme Court Ordinance, with some minor modifications. Section 19 of the Supreme Court Ordinance is regarded, generally, as central to the introduction of English law into British West Africa ${ }^{\mathbf{6}}$. For that section may be found in all former Britsh colonies in West Africa. This introduction of English Law was achieved by placing limits upon the application of the existing Tribal systems of Laws, so that the English Laws that were introduced provided the alternative system for adjudication in each territory. The Supreme Court Ordinance has now been adopted in each of the new States ${ }^{7}$ within the Federation of Nigeria. Section 19 reads:

Nothing in this Ordinance shall deprive that Supreme Court of the right to observe and enforce the observance, or shall deprive any person of the benefit of any Law or Custom existing in the said colony and Territories, subject to its jurisdiction, such law or custom not being repugnant to natural justice, equity, and good conscience, nor incompatible either directly or by necessary implication with any enactment of the colonial legislatures existing at the commencement of this ordinance, or which may afterwards come into operation.

Such Laws and Customs shall be deemed applicable in causes and matters where the parties thereto are natives of the said colony or territories, and particularly, but without derogating from their application, in other cases.

In causes and matters relating to marriage and to the tenure and transfer of real and personal property, and to inheritance and testamentary dispositions, and also in causes and matters

\footnotetext{
3 Ibid., s. 20.

4 The 1863 enactment war re-enacted with minor modifications in Act No. 1 and Act No. 9 of 1864; Act No. 5 of $1865 ;$ Act No. 7 and Act No. 8 of 1866; Act No. 1 of 1888; Supreme Court Proclamation Ordinance, No. 6 of 1900; Act No. 6 of 1914; Supreme Court Amendment Ordinance, No. 46 of 1933; Act No. 23 of 1943. All these were enactments of the Gold Coast, applicable to the whole of British West Africa.

5 A comparison of Act No. 3 of 1863 of the Gold Coast with the following regional statutes should show that there is no substantial difference between the two. The regional statutes of Nigeria, in question are: North: High Court Laws, cap. 49. (Section 34, corresponds with Section 19 of the Supreme Court Ordinance). Mid-Western: High Court Laws, Act No. 9 of 1964. (Section 13, corresponds with Section 19 of the Supreme Court Ordinance). Eastern: High Court Laws, cap. 61. (Section 20, corresponds with section 19 of the Supreme Court Ordinance). Western: High Court Laws, cap. 44. (Section 12, corresponds with section 19 of the Supreme Court Ordinance). Lagos: (Federal state) Section 19, of the Supreme Court Ordinance of 1964.

6 See Footnote 13 where the corresponding sections in the former four regions have been mentioned. The four regions have now been sub-divided into twelve states. Each state inherited the statute law of the former regions to which these, geographically, corresponded. Namely, the laws of the former North were extended to include North Eastern, Kano, North Central and Penue Plateau. vhe laws of the Mid-West now applies to the State of Mid-West. The laws of the former Eastern region now applies to the East-Central, South Eastern and the Rivers States. The laws of the former Western region now applies to the North-West, Western and Kwara States. The laws of the Federal Territory of Lagos has remained unchanged.

6a Allot (A), New Essays in African Law, Butterworths, 1970, pp. 158-159.

7 Fns. 5 and 6.
} 
between native and Europeans where it may appear to the Court that substantial injustice would be done to either party by a strict adherence to the rules of English Law.

No party shall be entitled to claim the benefit of any local Law or Custom if it shall appear either from express contract, or from the nature of the transactions out of which any suit or question may have arisen, that such party agreed that his obligations in connection with the transaction should be regulated exclusively by English Law. And in cases where no express rule is applicable to any matter in controversy, court shall be governed by the principles of justice, equity and good conscience ${ }^{8}$.

Section 19 lays down two situations under which native law and custom may apply. First, where the parties to a dispute are natives. Second, where one of the parties to a dispute is a native and the other is a non-native, and where "it may appear to the Court that substantial injustice would be done to either party by a strict adherence to the rules of English Law." It further lays down three situations where the native law and custom should not apply. First, where the native law and custom in question is "repugnant to natural justice, equity and good conscience, where it is incompatible directly or by necessary implication with any enactment of the colonial legislature existing at the commencement of this Ordinance, or which may afterwards come into operation it should not be applied. Second, where the dispute is between a native and a non-native and adherence to English law does not seem to result in an injustice to either party, then too the Native Law and Custom should not apply. Third, where the parties to the dispute have agreed by express contract or impliedly by adopting a particular pattern of trading, that their disputes will be subjected to the English $\mathrm{Law}_{\mathrm{a}}^{\mathbf{8}}$, the Native Law and Custom becomes displaced by implication. Of these the principal limitation is "repugnancy to natural justice, equity and good conscience".

It is over this latter restriction, which is applicable to the adjudicatory processes of both the Native Courts ${ }^{9}$ and of the non-native courts ${ }^{10}$ that a wide disparity may be detected in their respective decision-making processes. The judges in the non-native courts to a large measure have had their basic training in the English Common Law and therefore their views' on "repugnancy to natural justice et al may have been conceived within a framework of reference very different to that utilised by a judge of a native court with a purely local upbringing. Loromeke v. Nekegho and Ayo ${ }^{11}$ presents a good example. There the parties were Nigerian members of the Urhobo tribe. The first defendant was the widowed wife of the plaintiff's brother. The second defendant was her father. According to Urhobo native law and custom, upon which their claim was based, the widow was required to marry a man chosen by her deceased husband's family. If she had refused to do so, that native law and custom required her to return one-half of the dowry she had received at marriage, and transfer the custody of the children of the marriage back to the deceased husband's family. In the present case the first defendant refused to marry the plaintiff, the choice of her deceased husband's family. The deceased's family there fore claimed the custody of the children and the return of one-half of the dowry she had once received. Allowing the wido's appeal, Simpson J. wrote:

... in the present case where in purported compliance with the custom the custody of the widow's children has been given by the lower court to a man whom she has refused to marry, the application of the custom is undoubtedly repugnant to natural justice, equity and good conscience $^{12}$.

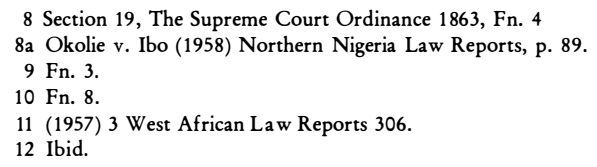


The result was the rejection of what probably was a settled custom among the Urhobos. The court surely had a way out without resorting to the "repugnancy" clause. The central issue could have been distilled into one of custody of children. Where custody of children is involved, section 26(1) of the Native Courts Law (of the North) ${ }^{\mathbf{1 3}}$ directs that:

... in any matter relating to the guardianship of children, the interest and welfare of the child shall be the first and paramount consideration.

Under that sub-section the Court could have rendered justice without resorting to the repugnancy clause. That could have saved the standing of Urhobo customary law to some extent. It is a well known fact that custody of children usually is a contentious issue in most tribal societies. The standards against which the judges of the Native Courts judge "repugnancy" is derived directly from the society they serve and to that extent the social infra-structure and the working of the legal system appear to be in harmony. The same view, however, cannot be held regarding the relationship between the non-native courts and the social infrastructure of a native Nigerian society.

The focus of this paper is to examine the native law and custom applied in four selected ${ }^{14} \mathrm{Na}$ tive Area Courts in Northern Nigeria and relate its application to the society over which those Courts preside. The selection of cases used in this paper are from a collection of 1500 decisions found as a result of empirical research conducted by a team of researchers led by the late Dr. D. J. Hill ${ }^{15}$. The entire research project which was funded by a grant from The Ford Foundation was conducted by The Ahamadu Bello University ${ }^{16}$ during the 1967-68 academic year.

\section{The Oath as a Rule of Substantive Law}

\section{(a) The Oath in a dispute concerning neither movables nor immovables}

In the "non-native" legal system the administering of an oath is considered as a rule of procedural law. It is considered as a necessary pre-condition to the admissibility of evidence. The oath, therefore, does not determine the substance of the issues that are raised in the dispute. This indeed is the effect attributed to the oath in the English legal system, upon which, the Nigerian legal system is modelled. This, however, is not the view taken by the native courts. The cases indicate that the oath has a substantive effect and to that extent the taking of an oath could settle the substantive question raised in the proceedings.

In Amadu Madaka v. Wakilin Kagara ${ }^{17}$, the plaintiff was at first married to one Dije. The plaintiff divorced Dije and she subsequently married the defendant. A child was born to Dije within 9 months of the dissolution of her marriage to the plaintiff. In these proceedings the plaintiff claimed the child as the father. The defendant contended that the plaintiff's wife had become pregnant during the last few weeks of her marriage with the plaintiff, in circumstances amounting to adultery with him. The Alkali (the tribal apellation for a judge of a native court), called upon Dije to take a "customary" oath supporting the defendant's conten-

13 Native Courts Law (of the North), cap. 78, s. 26 (1). Similar provisions may be found in the other regions too. Customary courts edict. (Mid-West), Edict No. 38 of 1966, s. 25 (1) and Customary Courts Law (West), cap. 31, s. 23 (1). See also, Diri v. Nyikwa K/M91/1965 (unreported) and Kasebiye v. Adeyemi 1. Nig. L.J. 125.

14 Fn. 1.

15 The late Dr. Hill passed away in March, 1979. He was then Senior Lecturer in Law at Qeen's University, Belfast. It was his enthusiasm and energy that made thr research project an unpralleled success given the conditions under which it was carried out. Namely, during a civil war in Nigeria.

16 In Zaria, in the North Central State of Northern Nigeria.

17 Case No. 1617/54, Daura Native Court, date uncertain. 
tion. She took the oath and the court thereupon dismissed the action, thus declaring the defendant to be the child's father. The decision in this dispute rested on the oath, and it appears to take the place of a rule of substantive law.

In Sule Dargage v. Sha aibu ${ }^{18}$, the plaintiff made an allegation that he did bribe the defendant a sum of $£ 3$ to have himself released from jail. The plaintiff further alleged that the defendant failed to have him released. By these proceedings the plaintiff claimed the return of the payment he had made to the defendant. The defendant denied ever receiving any mony from the plaintiff. The native court was not concerned with the concept of illegality that such a transaction may raise under the English Common Law. The Alkali called upon the defendant to take an oath to the effect that he did not receive such a payment from the plaintiff. The defendant took the oath and the Native Court dismissed the plaintiff's action.

In Usman Maimazari v. Alhaji Magiji ${ }^{19}$, the plaintiff alleged that the defendant had sold him a horse. It was also alleged that at the time of the sale, the defendant had not informed the plaintiff that the horse "was stubborn". The horse had the tendency to be unruly. This, according to the English Law could be characterised as a latent defect. The defendant, however, submitted that he knew of these qualities and had clearly informed the plaintiff of them. The Alkali, thereupon directed the defendant to take an oath in support of his submission. The defendant took his oath and the action against him was dismissed. Again, in Wodi Daneji v. Dabo Daneji ${ }^{20}$ the court used the oath to determine whether the defendant was the father of the child enventre. The plaintiff claimed that she was seduced by him. The defendant denied that allegation. There again the defendant took his oath and the action against him was dismissed upon that ground.

These cases suggest the use of the oath for the same purposes as for which a rule of substantive law is used by the English legal system. In each case the reliance of the native court upon the oath could be justified by the strong religious beliefs held by the society over which it presides. Superstition, the belief in magic, the attachment to cults and supernatural powers and the commitment to the notion of omnipotence of the family gods makes this process for the adjudication of disputes an effective one. The Case law suggests that the Alkalis do resort to the oath when there are no witnesses or the evidence before them is inconclusive. The oath has been used in a variety of disputes. It has been used in disputes concerning the Restitution of gifts given in anticipation of a marriage that has either failed or has not taken place ${ }^{21}$. In such cases the oath decides, conclusively, the question as to whether the plaintiff did give the gift which he claims to have given. In that sense the oath plays the role of mixed fact and law. The oath has also been used to determine the nature of a transaction: was it a loan or a gift ${ }^{22}$. In this sense the oath takes the guise of a rule of substantive law. In these disputes the party that takes the oath in each case is the defendant. Where the defendant refuses to swear, the Native Courts have come down on the side of the plaintiff's claim. In none of these cases has the Alkali required the plaintiff to take an oath in support of his claim. The reason for this may be found in the belief that once an allegation is made against a person his guilt or innocence becomes the concern of the super-natural and he will therefore be required to answer truly to his God. The method open to the defendant to have the plaintiff punished for making a false allegation against him is bymaking the plaintiff a defendant in the eyes of God. This is done by raising in a separate action the issue that the plaintiff in the first action had accused

\footnotetext{
18 Case No. 3/450, Daura Native Court, decided on 10th September, 1954.

19 Case No. 52, Daura Native Court, decided on 19th January, 1957.

20 Case No. 57/1296, Daura Native Court, decided on 26th June, 1967.

21 Haru v. Alti, Case No. 184, Daura Native Court, 13th March, 1957, Amadu v. Zulai, Daura Native Court, Case, Case No. 562/57, date of decision uncertain (1957).

22 Kadabo v. Maitsamiya, Case No. 161/1812, Funtuwa Native Court, 28th April, 1953.
} 
the defendant wrongly or maliciously. In such an action the plaintiff of the first action would be required to answer truly before his God as to whether he did speak the truth when he made the original allegation against the present plaintiff. This explains why in these proceedings it was only the defendant that was subjected to the oath, leaving him to proceed against the plaintiff in a subsequent proceeding. The rules of Evidence derived from the English Law would not recognise such an approach to adjudication.

Different considerations appear to prevail in disputes concerning title to immovables and movables and, therefore, a different explanation may become necessary for the way in which the oath is used in such disputes.

\section{II(b) The Oath in a Dispute Concerning Immovables}

In African tribal societies land is regarded as a subject for common ownership rather than for individual ownership ${ }^{23}$. This idea of common ownershipappears to have a link both with the family at the kinship level and with the tribe at the societal level. At either level land is recognised as a species susceptible to individual possession but not to individual ownership. Individual possession of land is linked to its utilisation. The individual who cultivates the land is recognised as being entitled to its produce. But the ownership is held in common among the members of the family within the tribe. This attitude to land has resulted in a number social consequences. First, tribal land is not subject to conveyancing laws. The precise extent of a native family at all times remain matter of some obscurity. Who the members of a family are, is not a matter that could be discerned with any certainity for the purposes of keeping records. Therefore, ownership is not subject to documentary evidence evinced from deeds of registration but by oral evidencewhich could raise a question of fact. Second, the importance of oral evidence in the ascertainment of rights to tribal land has made the administering of an oath a matter of critical importance. Third, the notion that land, in the folkish context is amenable to common ownership rests on the belief among tribal societies that land belongs to the diety and as such should be shared equally among all subjects. Central to this belief is that a secular judge, when in doubt, must do justice by dividing the earth equally among the disputants. The Alkalis in the four tribal areas selected for the purposes of this paper, appear to follow the foregoing folklore in their decision-making processes.

The case of Tsmiya v. Baru ${ }^{24}$ provides a typical example. The plaintiff brought this action claiming the return of a farmland which he says he had "pledged" to the defendant for $£ 10$. The defendant submitted that the farmland was in fact sold to him for that price. The question before the native court was whether the transaction was a sale or a pledge. There being no witnesses the Alkali called upon the plaintiff first and then upon the defendant, to take an oath. Neither of them were willing to take the "customary" oath. The Alkali thereupon ordered the land to be divided equally between the two disputants. In Bello v. Murnai ${ }^{25}$ the issues were similar to those raised in Tsmiya v. Baru. The plaintiff claimed that he had pledged the land to the defendant while the defendant claimed to have purchased it. Each party to the dispute provided two witnesses to support their claims. It appeared from the evidence that

23 Meek (C.K.), Land Law and Custom in the Colonies, Frank Cass \& Co. Ltd., 1968. Chapter II. See also Fn. 1 at p. 19 (ibid), where. Meek quotes from Schapera (I) Land Tenure in the Bechuanaland Protectorate, 1943: "In every instance the possessor of land is entitled merely to its use, and not to absolute ownership. Should he go away temporarily he can take up the land again on his return. Land passes only by way of gift, inheritance or gratuitous loan. It is never treated as a commodity that can be sold or hired out. There is, therefore, no opportunity for land speculation and no incentive to the acquisition of large holdings from which a return can be derived in the form of purchase price or rent. Tribal law moreover limits the amount of land that people may hold. (pp. 44-46)."

24 Case No. 57/644, Baure Native Court, decided on 27th March, 1957.

25 Case No. 57/382, Daura Native Court, decided on 30th May, 1957. 
both parties sincerely believed in their individual assertions and, therefore, it appeared that there could only be a misunderstanding in the way they had negotiated the transaction. The Alkali, thereupon directed each party to take the oath. Both parties swore an oath in support of their individual contentions. The native court thereupon ordered the land to be partitioned equally between them. This method of dispute settlement will work provided that the litigants have a commitment to the oath. This naturally places a heavy emphasis on the folkish ways that forms the social infra-structure of the society over which the court presides.

In Zango v. Zango ${ }^{26}$ the plaintiff claimed that the land in question was loaned to the defendant while the defendant submitted that it in fact was sold to him by the plaintiff. The Alkali at first called upon the plaintiff to take the oath. He refused, and thereupon the defendant was requested to take the oath. The defendant took the oath and the Alkali thereafter dismissed the plaintiff's action. In Sandamu v. Fulani ${ }^{27}$ the plaintiff claimed that he had pledged the farmland to the defendant for 20 shillings. When he took the 20 shillings to the defendant to have the pledged farm redeemed, the plaintiff alleged that the defendant refused to return the farmland. The defendant's case was that the plaintiff in fact sold the land for 26 shillings and therefore he was not the pledgee but its purchaser. There being no witnesses to this transaction, the Alkali called upon the plaintiff to take the oath. The plaintiff took the oath. The Alkali thereupon invited defendant to take the oath. The defendant refused and the court thereafter ordered the defendant to return the land to the plaintiff. Zango v. Zango and Sandamu v. Fulani suggest the way the Courts would decide where the oath is taken by one of the two contending parties. It would appear that the oath is decisive as to the way the court may ultimately find. The party that takes the oath will succeed in his claim.

From the foregoing cases four basic rules seem to emerge:

1. Where in a dispute concerning land both parties to the dispute either take the oath or refuse to take the oath the judgment of the Court as a general rule orders the partitioning of the land equally between the two parties.

2. Where in a dispute concerning land only one of the two parties take the oath, the judgment of the Court as a general rule is that the claim made or the denial made by the party that takes the oath gains the acceptance of the Court.

3. The utilisation of the oath as a method for the adjudication of disputes takes place normally where there is either no evidence or the available evidence appears to be in conclusive on the issues in dispute.

4. In each case the oath plays the part of a substantive rule of law.

These four rules appear to be observed generally by the Native Courts chosen ${ }^{28}$ in the geographical area ${ }^{29}$ selected for the field work. Of the 300 cases that have been examined for the purposes of this paper, 34 cases have been selected for the present section, concerning land. Of these, three cases decided by the same Native Court on the same day appear to run counter to the first of the four rules stated above. In Barau v. Adamu ${ }^{30}, B$ arau v. Ilu ${ }^{31}$, and Liman v. $\mathrm{Ai}^{32}$, all three cases decided on the 7th July, 1957, the Alkali dismissed the action and left the land in the defendant's hand when none of the parties to the disputes agreed to take the requisite oath. Those three decisions quite clearly run counter to the first rule enum-

\footnotetext{
26 Case No. 57/976, Daura Native Court, decided on 15th May, 1957.

27 Case No. 57/211, Daura Native Court, decided on 27th March, 1957.

28 Fn. 1.

29 In the Province of Katsina, in North Central Province in Northern Nigeria.

30 Case No. 57/314, Daura Native Court, decided on 7th May, 1957.

31 Case No. 57/315, Daura Native Court, decided on 7th May, 1957.

32 Case No. 57/316, Daura Native Court, decided on 7th May, 1957.
} 
erated above. As these three cases have been decided by the same Alkali, it may be concluded that they do not represent the law in this matter. They could be explained as a result of a confusion between the effect of oaths on movables with the effect of oaths on immovables, as the next section shall show.

\section{II(c) The effect of an Oath on Movables}

In tribal societies the distinction between ownership and possession of movables is not clear. Possession, in a tribal society, is regarded as raising a presumption of ownership. The person who possesses a movable in a tribal society with the intention of excluding all others from its use and enjoyment receives the same recognition as that received by an owner under the English Common Law. In a tribal society, therefore, possession supercedes all other considerations and accordingly the rights of the possessor is not that easily disturbed. Arising out of this the case law suggests, that the rules regarding the taking of oaths in disputes concerning movables, is clearly different from those suggested in the previous section.

In Dankama v. Mato et. al. ${ }^{33}$ the plaintiff claimed that after his father's death he had placed eight heads of cattle in the defendant's care. That was done because the plaintiff was unable to look after the cattle. The arrangement was that the defendant "could use and enjoy the products" provided he returned the cattle with any additions to the herd, whenever the plaintiff needed them. The defendant's submission was that the plaintiff, at his father's death, gifted the herd to him because he was unable to look after them. While the plaintiff claimed the transaction to be one of loan the defendant submitted that it was a gift. As there were no witnesses, the Alkali directed the two parties to take "customary oath". Both parties took the oath. The indication, therefore, became clear that there could have been a basic misunderstanding of the nature of the transaction. There being no other way open to the Court to ascertain the true nature of the transaction the Alkali recognised the possessor's right to continue undisturbed his possession of the cattle. The action against the defendant was dismissed. If the dispute concerned land then the fact that both parties to the dispute had taken the customary oath would compel the Court to partition the Corpus and give each party an aliquot share in it.

In A'I v. Yau Biya ${ }^{34}$, the plaintiff alleged that she left 44 articles of domestic utensils with the defendant for safe keeping. But on demand the defendant admitted receiving only 14 of them. The present action was brought to recover all 44 of the items concerned. Neither of the two parties were willing to take the "customary oath" in support of their respective contentions. The Alkali ordered the defendant to return the 14 articles which she had admitted to receiving. As for the rest of the articles the action was dismissed. A large number of cases suggest that where the plaintiff at the outset takes a "customary" oath in support of his contention, then the only defence the defendant has, is to answer the plaintiff's claim with a counter oath. In that event, when both parties have taken the oath, the result will be as in Dankama v. Mato.

In Audu Daura v. Saiyadi Daura ${ }^{\mathbf{3 5}}$, the plaintiff swore that the defendant had failed to return several household articles which he had left in the custody of the defendant. The plaintiff did not provide any witnesses. The defendant at that point swore that he did receive the articles mentioned but that they were stolen from his house by thieves. The Native Law recognised

33 Case No. 56/149, Daura Native Court, decided on 20th March, 1956.

34 Case No. 3/452, Daura Native Court, decided on 11 th September, 1957.

35 Case No. 57/1282, Daura Native Court, decided on 25th June, 1957. 
that the gratuitious bailee was not liable for the acts of third parties, in the absence of negligence in the bailee. There being no such negligence, the Court dismissed the action. In contrast in Hauwa v. Tunau ${ }^{36}$ the plaintiff alleged that she left a cow with the defendant for use and enjoyment in the nature of a gratuitous bailment. She further contended that the cow had subsequently produced 3 calves. By the present action, the plaintiff claimed the return of all four animals. The transcript (when translated) reads:

"the court asked the defendant whether he would swear to an oath that the cow and the calves claimed by the plaintiff were not hers. And he said he would not swear. The Court then asked the plaintiff to swear in support of her claim that the cow and her calves belonged to her. She said she would swear and did swear. Judgment: For the plaintiff (sic)". ${ }^{37}$

The distinction between cases discussed earlier ${ }^{38}$ involving disputes to neither immovable property and cases discussed here, is that: while in the former the Native Courts do not require the plaintiff to take the "customary" oath before the onus of proof shif ts to the defendant, here the plaintiff must first take the oath, and the onus would only thereafter shift to the defendant. It may be recalled that in the cases falling within the first category the mere accusation could subject the defendant to a duty to speak truly allegedly under the watchful eye of his God. And, therefore, his oath would be relevant to the result of the dispute. However, in a dispute involving a movable, the mores of the society supports the presumption that the possessor cannot be disturbed in his right to posses without the full effect of an oath. The oath, therefor, must precede the movement of the burden of proof from the plaintiff to the defendant. It is this that requires the plaintiff to take his oath first.

The cases suggest three basic rules applicable to disputes concerning movables.

(1) Where both parties to the dispute either take the oath or refuse to take the oath, the general rule is that the Court shall not disturb the right of the possessor to continue his possession of the Corpus.

(2) In a dispute concerning movables, unless the plaintiff takes the oath, first, the onus to take a counter oath does not shift to the defendant. (In this respect these disputes do differ from those that involve matters other than immovables or movables. ${ }^{39}$ In each such case a mere allegation would require the defendant to take an oath as a substantive defence in answer to such an allegation.)

(3) Similar to the effect of a $n$ oath in disputes involving land, the oath in these cases to take the appearance of a rule of substantive law.

\section{Divorce}

The concept of marriage in Native societies is based more upon a contractarian theory and less upon a concept of Status. The contract of marriage preceded by a period of Betrothal projects all the attributes of a contract of sale rather than a process leading towards the creation of a status in the eyes of the law. Dr. Obi has described this notion of marriage in his book concerning Family Law in Southern Nigeria in this way:

Betrothal may be defined as a formal agreement under customary law between a woman and/or her family on one hand and a man and/or his family on the other, whereby the woman's family agree to give her in marriage to the said man, the man and/or his family, for their part, undertaking to have the woman as wife, to pay any agreed bride price (dowry) and generally to fulfil the usual obligations of "in-laws."

36 Case No. 328/10, Daura Native Court, decided on 10th May, 1957.

37 Ibid.

38 See Section II (a) above.

39 Ibid. 
Betrothal is "formal" in more than one sense of the word. First, it is normally a formal expression, before one or more witnesses, of a prior informal agreement between the prospective spouses or their families to marry or be given (and accepted) in marriage as the case may be. Secondly, the transaction normally follows a fairly well defined procedure or form in any given society, and is everywhere sealed, as it were, with commensality of one kind or another. (The usual victuals are kola nuts or some other fruits and nuts, drinks and a good meal, in that order).

A contract to marry, as the name implies, is a legal obligation between a man and a woman to take each other as husband and wife by one of the methods prescribed by the general law. This is, in essence, a transaction between the prospective spouses as individuals, not between their respective families ${ }^{40}$.

The basic difference between the English Law and the Native Laws and Customs regarding marriage may be explained on the basis that the native laws do not consider marriage as a "status creating" act but merely as a legally binding contract giving rise to a bundle of rights and duties recognised by the Native Law and custom of the particular tribe. That must indeed explain some of the differences one would notice in Divorce applications that have come before native courts. Of the sample of 300 cases that have been chosen for the purposes of this paper, as mayny as 64 dicisions involve divorce applications. Of these 64 dicisions the majority dealt with grounds for divorce. Of these, those decisions based upon such grounds such as cruelty, adultery and desertion which fall both within the Native Court sub-system and the Nigerian Court system have been discarded. What is proposed here is to examine those divorce petitions based on grounds peculiar to the Native Law and custom and attempt to explain them, in terms of the contractarian theory which has been set out above.

The decision of Indo Ta Sabuwa v. Miko Na Mimakwame ${ }^{41}$ affords a convenient starting point. The following translation fo the transcript provides a clear picture of the dispute: "Indo, 45, wished to be divorced from her husband on the ground that she no longer loved him. Her husband, Miko, 55, agreed to be separated from her, but on the condition that she refunded a sum of $£ 2$. 9s. due to him and a set of native clothing. The wife was not asked about the claims of her husband, but rather, the Alkali confirmed the money as due to the husband. As for the clothes the Alkali said that 'they had been taken by the marriage' and so the husband could not re-claim them. Judgment: The Alkali ordered Indo to refund $£ 2$ out of $£ 2.9 \mathrm{~s}$ to the man and the marriage was dissolved. (sic)" 42

The decision rests on the foundation that the wife had breached an contract and therefore was required to restitute for some of the losses suffered by her husband. However, if the husband had in anyway been at fault, the wife may not have been required to make restitution to the husband. In either case the law does recognise that the parties are, indeed, free, to breach the contract for whatever reason. This resembles more of a contract rather than a Status creating transaction. In some decisions the Native Court is merely asked to take note of the fact that the wife had already been divorced by the pronouncement of a "talaq" by her husband. The "talaq" which releases the wife from the bonds of mariage by the unilateral repudiation of the contract of marriage, has no intervening legal process. The "talaq" could be pronounced by the husband at any time and from anywhere. This is a good indication that marriage in these cases do not create a Status but remain a mere contractual obligation. For, of it was otherwise, then the interposition of a judicial proceeding would be an essential pre-requisite to

40 Obi (S.N.C.), Modern Family Law in Southern Nigeria, Sweet \& Maxwell, 1966, P. 103.

41 Case No. 328/10, Daura Native Court, decided on 10th May, 1957.

42 Ibid. 
TABLE 1

The Oath: Who takes it first?

Dispute involves

neither movables

Dispute involves

Dispute involves

nor immovables immovables only movables only

\begin{tabular}{l|l|l|l|}
\hline $\begin{array}{l}\text { Plaintiff takes } \\
\text { the oath }\end{array}$ & & & \\
\hline $\begin{array}{l}\text { Defendant takes } \\
\text { the oath }\end{array}$ & & & \\
\hline $\begin{array}{l}\text { Both parties } \\
\text { must take the } \\
\text { oath }\end{array}$ & & & \\
\hline
\end{tabular}

TABLE 2

The Oath: The Result

Dispute involves

Dispute involves

Dispute involves

neither movables

only immovables

only movables

nor immovables

\begin{tabular}{|c|c|c|c|}
\hline $\begin{array}{l}\text { The result where } \\
\text { Plaintiff alone } \\
\text { takes the oath }\end{array}$ & $\begin{array}{l}\text { Plaintiff is } \\
\text { suited }\end{array}$ & $\begin{array}{l}\text { Plaintiff is } \\
\text { suited }\end{array}$ & $\begin{array}{l}\text { Plaintiff is } \\
\text { suited }\end{array}$ \\
\hline $\begin{array}{l}\text { The result where } \\
\text { defendant alone } \\
\text { takes the oath }\end{array}$ & Defendant suited & Defendant suited & Defendant suited \\
\hline $\begin{array}{l}\text { The result where } \\
\text { both parties take } \\
\text { the oath }\end{array}$ & Action dismissed & $\begin{array}{c}\text { Equal distribution } \\
\text { of property in } \\
\text { dispute }\end{array}$ & Defendant suited \\
\hline $\begin{array}{l}\text { Neither party } \\
\text { takes the oath }\end{array}$ & Action dismissed & $\begin{array}{c}\text { Equal distribution } \\
\text { of property in } \\
\text { dispute }\end{array}$ & Defendant suited \\
\hline
\end{tabular}

any alteration of the status of being married. In Salwai v. Ibirahim ${ }^{43}$ the wife applied to the Court requiring it to take notice of the fact that she had been divorced by her husband using the "talaq", some three months prior to her application. The husband, the respondent, admitted to the administration of the "talaq". The Alkali thereupon declared that the applicant was free to re-marry since she had completed the 3 month period of Idda. It does appear in these cases that the wife's access to the native courts is limited for the purposes of having her right to re-marry declared. Such a declaration is essential because it is the woman and not the

43 Case No. 777, Baure Native Court, decided on 20th March, 1957. 
man that is required to observe the three months of continuous chastity or Idda after each divorce, without which she could not acquire the capacity to re-marry. If she were to re-marry before that period, her marriage according to her personal law, would be a nullity. The cases indicate that in each instance where the husband had pronounced the "talaq" the appearance of the wife before a native court war merely for the purposes of having her period of Idda ascertained and determined by the Court ${ }^{44}$.

Besides these cases where the husband uses the "talaq", there are a number of decisions in which the wives have successfully claimed the dissolution of their marriages upon such grounds as: husband's insistence that the wife should go out and cut firewood $\mathbf{4 5}$ "the wife's assertion that she hates her husband ${ }^{46}$ ", "the husband is alleged to be afflicted with leporsy47", or "that the husband has refused the wife permission to visit Mecca on a pilgrimage ${ }^{48 "}$ ". In each case the Alkalis had found that the wife had suficient grounds to rescind the contract of marriage. In each case, therefore, the husband forfeited his right to reclaim the "dower". However, there is al line of cases where the wife had exercised her right to rescind the contract of marriage in circumstances in which the husband had in no way being at fault. In such cases the wife was ordered by the native court to return the dower to her husband. In Hauwa Maidobi v. Ako Sharawa ${ }^{49}$ the wife claimed that she no longer loved her husband, and, therefore, she asked for the dissolution of her marriage. This was allowed, but she was ordered to return a sum of $£ 39.11 .8 \mathrm{~d}$, being money that the husband had spent towards celebrating their marriage. In each of these cases the wives were compelled to seek the aid of the native courts merely because the Native Law did not give her a power to rescind the contract of marriage unilaterally, without the interposition of the tribal chief's "fiat". The chief's "fiat" in this case had been substituted by the Alkali's order issued through a native court in the locality. The case law appears to suggest some basic propositions. These are:

(1) The concept of marriage in the tribal society in questions was based upon contract and not on status. Studies undertaken by others generally into African tribal societies appear to arrive at a similar conclusion for other African societies as well.

(2) The power to divorce is inherent in the husband. He may exercise that power without reference to any court or Native Authority. In the Islamic Law this may be called the Talaq. But in other systems, this right appears under different forms and different names.

(3) The unilateral use of the Talaq could compel the wife to seek the assistance of the Native Courts to fix the period of Idda or the period of her continuing chastity. Besides that, once released from the bonds of marriage by the unilateral rescission of the contract, she has nothing further to seek from the native court.

(4) However, if she wishes to rescind the contract of marriage unilaterally she could do so for any apparent reason or for no reason at all including the reason that she had ceased to love him. In each case, unless there is some element of fault in the husband, she must refurn not only the dowry but sometimes as in Hauwa Maidobi v. Ado Sharawa the expenses that the husband had incurred in marrying her.

(5) None of these customary Native attitudes to the instituion of marriage are recognised by the English Law which forms the Nigerian legal system distinct from the Native Law and custom sub-system with which we have been concerned here.

44 Case No. 728, Daura Native Court, decided on 1st June, 1955.

45 Laure Ta Garni v. Gagaran Na Garni, Case No. 1733, Daura Native Court, decided on 22nd December, 1955.

46 Mariyi Madaka v. Amadu Madaka, Case No. 57/221, Daura Native Court, decided on 30th January, 1957.

47 Jaru Ta Maiaduwa v. Tomo, Case No. 748, Daura Native Court, 6th June, 1955.

48 Awaita Baure v. Sarkin Fada na Baure, Case No. 692, Baure Native Court, decided on 1st May, 1952.

49 Case No. 1314/56, Daura Native Court, date uncertain. 


\section{Conclusions}

It is important to recognise the differences in the ideological and ethical bases upon which the two systems appear to rest. The connecting factor between the two systems is the rule of repugnancy. The Nigerian legal system which is drawn of the English legal system has declared that notions repugnant to "equity, justice and good consience" should receive no legal enforcement from either ${ }^{50}$ court system in the Federation. This kind of approach, restricting and thus limiting the scope of indigenous laws which have been born out of a social interaction in native societies, have to a large measure caused an incongruency between the social infra-structure and the workings of the Nigerian legal system when considered as a whole. The "repugnancy" clause could be found in most former British colonies in Africa. In a landmark decision handed down by the Tanganiyka High Court (as it then was) in Gwao Bin Kilimo v. Kisunda Bin Ifuti ${ }^{51}$, Mr. Justice Wilson explained what the attitude of British Courts should be to indigenous laws. He said:

"But on the other question-as to whether the application of the 'law' in question to the present case would be 'repugnant to justice and morality' - and I hold more positive views, though the meaning of that phrase. Morality and justice are abstract conceptions and every community probably has an absolute standard of its own by which to decide what is justice and what is morality. But unfortunately, the standards of different communities are by no means the same. To what standard, then, does the Order in Council refer-the African Standard of Justice and Morality or the British Standards? I have no doubt whatever, that the only Standard of Justice and morality which a British Court in Africa can apply is its own British Standard. Otherwise we find ourselves in certain circumstances having to condone such things for example, as the institution of slavery ${ }^{52}$."

The result of this attitude is clearly to create a gap between the native societies and the legal system taken as a whole. Several decisions from Nigerian Courts suggest such an increasing gap. In Charles King Amachree v. David Kallio and others ${ }^{53}$ the question was raised as to who among the disputants to the present action had the customary right to fish in the New Calabar River including its creeks and ponds. The case raised two competing rights between two native tribes and therefore the Native Law and Custom applicable to the two tribes could have been most relevant to the decision. The Nigerian Supreme Court hearing the Appeal spent no time in declaring that they were neither interested in seeking out the Native Law and Custom applicable to the dispute before them, nor did they think there was any available which would be revant to the dispute. In either case the court was content to say that:

" - if such law or custom were clearly proved, (the Court) should be prepared to hold that it was contrary to the principles of Natural Justice and Equity, and that it was accordingly not enforceable by this Court ${ }^{54}$."

The judgment of the Court was to deny a customary right to fish in the river and to declare that the New Calabar River was an "Ocean Highway". It seems apparent that the Court was not interested in the fact that the dispute did not raise the question of the River being used as an "Ocean Highway" but merely to seek a determination of the customary right which the two tribes had, to fish in the New Calabar River. The right to fish and the right of free navigation does not appear to be conflicting rights. If the Court had separated these two issues then

50 This is the combined effects of footnotes 3 and 8 .

51 (1938) 1. Tanganiyka Law Reports (R), p. 403

52 Ibid., p. 405.

53 (1911-1914) 2 Nigerian Law Reports, p. 108.

54 Ibid., p. 111. 
there should not be any objection for determining the question of the customary right to fish under the Native Law and Custom prevailing in that area. This confusion may be seen in the following passage from Ross J's judgment with the rest of the Court concurred:

The New Calabar river is the great high road, not only from the sea to the portions of the land occupied by the Plaintiffs, but beyond those parts to the lands occupied by persons who are not parties to the suit. From time immemorial, this highway must have been the only route for all trade to and from the towns in the delta, as shown on the map. For this Court to grant to any one section of the inhabitants the sole rights to use und fish in or any sole right over this great natural highway in the absence of the strongest possible evidence, would be a proceeding fraught with danger to the community at large, against every principle of the law applicable to the country, and to all such rivers, and against public policy and natural justice ${ }^{\mathbf{5 5}}$. In Rasika Yinusa v. Adesubokan. ${ }^{56}$, the question before the Courts was the validity of a will. The testator who both a Moslem and a native of Northern Nigeria from the province of Katsina, in which the empirical research mentioned here into Native Courts was conducted, died leaving a will. The Will had excluded the Koranic heirs which under his personal law rendered the testamentary instrument invalid pro tanto. The Will, however, was valid unter the English Wills Act of 1837 which had become a part of the law of Northern Nigeria. Both at the Native Courts level and at the level of the North Central State High Court ${ }^{57}$ it was held that the will pro tanto was invalid. Delivering the judgment of the High Court, Bello J. wrote:

“- a Moslem can make a will under the Wills Act 1837 but by virtue of section 34 (1) of the High Court Law he has no right to deprive his heirs, who are entitled to share his estate unter the Moslem Law of their respective shares to which they are entitled under the Moslem Law 58 ."

The judgment of the Court brought three issues clearly into focus. First, the court recognized that a Moslem Native of Nigeria had the power to make a will under the Wills Act of 1837 , but in the exercise of that power he cannot abandon his personal law and thereby exclude the Koranic heirs altogether from his Will. Second, where he does exclude the Koranic heirs, his Will is valid but the bequests will be cut down pro tanto unless the heirs ab intestato, to whom two-thirds of his property, both movables should go, confirm the provisions of the will at the time of probate. Third, the Court expressed the view that a Moslem could validly make a Will under the Wills Act of 1837 and validly exclude the Koranic heirs, if he were to renounce Islam. That would necessarily make him liable for the crime of Apostasy which carries a penalty of death ${ }^{59}$. The Koranic heirs were successful before the High Court. The non-Koranic heirs appealed from that decision to the Federal Supreme Court ${ }^{60}$, the highest Court of Appeal for the Federation. The Federal Supreme Court allowed their appeal while reiterating the position that any personal law which did not conform to the Wills Act of $1837^{61}$ must be considered as inapplicable in Nigeria. In this respect, Ademola F. C. J. observed:

\footnotetext{
55 Ibid., pp. 111-112.

$56 \mathrm{Z} / 23 / 67$, decided on the 30th October, 1968.

57 Ibid.

58 Ibid.

59 Shorter Encyclopedia of Islam, p. 413 and Zwemer, The Law of Apostasy, London, (1924).

60 S.C. $25 / 70$, decided on 17 June, 1971.

617 Will. 4 \& 1 . Vict. c. 26
} 
"As we stared earlier, a proper construction of sub-section 34 (1) of the High Court Law62 can only apply such Moslem Law which is not incompatible with the Wills Act ${ }^{63}$."

The High Court Law to which the Federal Supreme Court referred was the one that contained the "repugnancy clause" to which reference has previously been made ${ }^{64}$. The two approaches taken under section 34 (1), by the two Courts; namely, the High Court and the Federal Supreme Court appear to be in opposition to each other. While the High Court was in favour of limiting the application of the Wills Act by the Moslem Law, the Federal Supreme Court, was content on eclipsing the Moslem Law by the provisions adopted from the English Wills Act. Having first quoted in verbatim, certain passages from Bello J's judgment, Ademola F. C. J. commented that:

"This clearly violates the provisions of the Wills Act, 1837 under which a testabor can dispose of his properties - real and personal - as he pleases. The provisions of the Maliki Moslem Law is undoubtedly incompatible with Section 3 of the Wills Act, 183765."

The last two decisions must indicate that the use of the "repugnancy clause" was instrumental in replacing the Native Law and Custom, to a large measure, by the English Common Law. To that extent the gap between the social infrastructure and the workings of the legal system has become widened.

In discussing disputes concerning land it was pointed out that the Native Land Tenure system did not respond to the sophistication of the English Land Law and conveyancing practices at the time. The absence of a concept of ownership as a serious element in native tenurial system rendered redundant the need to register title to land under the law of conveyancing. The failure to react to these realities made native land transactions somewhat incomprehensible to the Nigerian legal system. To that extent the native access to justice, if it were to take the native social infra-structure into consideration, needed to stop at the subsystem level, namely at the level of the native courts. Had the dispute proceeded any further, then the gap between the system and subsystems would become such that the ultimate solution may have to conform to the rules in the system rather than to those of the sub-systems. Few native disputes, therefore, went further than the sub-system level and those that did go beyond that level had some real problems to face. Two examples from the Nigerian Courts should suffice to substantiate this view. The two decisions are Griffin v. Talabi66 and Adjei v. Dabanka ${ }^{67}$. In Griffin v. Talabi ${ }^{68}$ a Native of Nigeria gave a document in respect of a sale of land. That document read:

"We shall be ready to convey unto the said purchaser the land aforesaid at any time that we may be called upon so to do, and that without delay69."

That document was given by one Duroda at a n alleged sale in 1928. The respondent claimed that upon the delivery of possession of the land in question he did become its owner by $\mathrm{Na}$ tive Law and Custom in 1928. The appellant submitted that notwithstanding that document he had become the owner of the land in 1946 under al deed of conveyance executed in his favour by a descendant of Duroda. The central issue was this. Should the transaction of 1928 be considered under the Native Law and Custom or under the English Law. If it was the

\footnotetext{
62 High Court Law (of the North), 1955, No. 8, s. 34 (1): "The High Court shallobserve, and enforce the observance of, every Native Law and Custom which is not repugnant to natural justice, equity, and good conscience, nor incompatible either directly or by implication with any law for the time being in force, and nothing in this law shall deprive any person of the benefit of any such native law or custom."

63 Fn. 60.

64 Fns. 3 and 8.

65 Fn. 63.

66 (1948) 12 West African Court of Appeal Report, p. 371

67 (1930) 1 West African Court of Appeal Report, p. 63

68 Fn. 66.

69 Ibid., p. 372.
} 
former then the respondent had ecquired a title to land some eighteen years prior to the conveyance of that land to the appellant. However, if the law applicable to the 1928 transaction was the English law, then, the document in question would be ineffective towards conveying a title to the land to the respondent. The central issue, therefore, was the proper law of the contract. The West African Court of Appeal, per Verity C. J. decided that:

"Had the parties thereto intended that the original transaction was to be one governed by native law and custom, completed upon payment of the purchase money and delivery of possession, there would have been no necessity for Chief Oloto to join in the subsequent conveyance as a vendor, nor would he have been described as a 'beneficial' owner had he divested himself of all interest in the land som (eighteen) years previously.

It is impossible for us to brush aside the terms of these two documents. They clearly evidence a transaction the nature of which is unknown to native law and custom, which are concerned neither with covenants to convey nor with the execution of formal conveyances. The respondent is not therefore entitled to claim the benefit of any 'local law or custom' by virtue of (section 19) of the Supreme Court Ordinance and the transaction must be deemed to be regulated by English Law. The alleged purchase in 1928 created no more than an equitable interest in the land, the legal title remaining in the vendor. By purchase in (1946) the appellant's predecessor in title, being a purchaser for value without notice, acquired the legal title ${ }^{70}$." Once the choice of law was made in favour of English Law the decision reached was both inevitable and predictable. The crucial question, however, was whether ,, convey" meant conveyance of the title or the conveyance of the possession to the land. The word itself is meaningless unless it is construed against the background of the land tenurial system in a tribal society. The Court did not think it was necessary to construct the word, ,convey" against the realities prevailing in a native society, but thought it would be adequate to construct that word against its meaning in the English Common Law. The latter, it must be emphasised, could have had no real relevance to a Nigerian tribal society in 1928 . The unreality of the approach taken by the Court needs little emphasis.

The second of the two cases, Adjei v. Dabanka ${ }^{71}$ concerned a mortgage. The plaintiff hat borrowed $£ 250$ from $X$ who was the predecessor in title to the defendant. The agreement evidenced in writing stated that the plaintiff had agreed to mortgage the land to $\mathrm{X}$, in order to provide a security for the loan. It was further agreed that the plaintiff would remain in possession of the land, but that $\mathrm{X}$ would become its absolute owner if the plaintiff failed to pay the principal and the interest within a year. After the expiry of a year, the plaintiff offered the payment of both the principal and the interest and claimed the property back from the defendant, who by now had succeeded to X's title. The defendant refused to return the land. The plaintiff was unsuccessful before the Supreme Court of Nigeria. The present appeal was heard by the West African Court of Appeal. Allowing the appeal the Court chose the English Law to govern the transaction raised in the dispute. The justification for this choice was that in a Native mortgage the mortgagee and not the mortgagor remained in possession. The Court, therefore, held that the transaction contained the elements that compelled the Court to consider its legal effect, not according to the Native Law and Custom, but according to the English Law. Therefore, it was held, that the transaction created not a native mortgage but an equitable mortgage, requiring the Court to order its redemption at the option of the plaintiff. Mr. Justice Michelin wrote:

\footnotetext{
70 Ibid., pp. 372-373.

71 (1930) 1 West African Court of Appeal Reports, p. 63.
} 
"It cannot also be held to be native mortgage in view of the fact that it is stated in the body of the deed 'that the said building shall remain in the possession use and control of the mortgagor who shall also draw and receive all rents accruing therefrom until the end of one year from the date of these presents. It is an essential element of a native mortgage that possession of the mortgaged premises should be given to the mortgagee at the time when the transaction takes place between the parties ${ }^{72}$."

Although in a great majority of decisions the Courts have pounced upon the use of such terms as "convey" or "mortgage" to justify the avoidance of Native Law and Custom, there are a very small number of decisions which have to a large extent attempted to interpret English legal terms used in documents or during transactions in light of Native Law and Custom. In Nwangwu v. Nzakwu ${ }^{73}$ while proceedings commenced by the respondent against the appellants for a declaration of title under native customary law to a piece of land were pending, both parties to that dispute agreed to grant a lease of that land to the Colonial Development Board. The land was described in the lease as "an estate in fee simple". And the agreement was that the party in whose favour a declaration of title was granted, would affect the lease in the Board's favour. The Court applying the Native Law and Custom made the declaration of title in the respondent's favour. The point raised in the present action was that "an estate in fee simple" was something which was unknown to Native Law \& Custom, and therefore, it was argued that the respondent who holds the land unter that law, was not entitled to the rental of $£ 4,320$ for the lease of a "fee simple".

The point that affects our conclusions may be found in the following passage from the judgment of the Federal Supreme Court. While dismissing the appeal Foster Sutton, F. C. J. said: "If by a reasonable construction the intention of the parties can be arrived at and that intention carried out consistently with the rules of law, it is the duty of the Court to take that course.

It is a fact that there is no such thing as a 'fee simple' under Native Customary Law, but the claimants to the land in question were Africans, and I have no difficulty in reaching the conclusion that there is no possible doubt that they intend a lease to be granted by the party who succeeded in the action...

There have been many cases in this country in which the expression 'fee simple' has been mis-applied in describing an absolute title to land subject to Native Customary Law, and, in my view, to hold that because the English term has been used in the present instance the agreement is a nullity would be an injustice an amount to turning one's back on common sense ${ }^{74}$."

It seems to be abvious that the Courts were willing to limit the application of Native Law and Custom when ever they thought they should do so as a matter of judicial policy. The method of judicial decision making in Nwangu v. Nzakwu stands in contrast to both Griffin v. Talabi and Adjei v. Dabanka. In each case it is a question of policy as to the extent to which the courts may consider the gap between the social infra-structure and the workings of the legal system should be closed or extended. The Courts in this area appear to use an accordian-like movement in the application of its judicial policy. In some instances the courts have given a wide lattitude to the Customary Law. In others they have restricted its use rather severely. The case law suggests no general policy that appear to guide the courts in its use of the judicial discretion allowed under Section 19 of the Supreme Court Ordinance 75 to which reference has been made earlier.

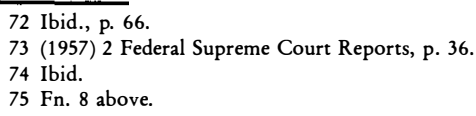


Although in matters of substantive law the Nigerian legal system did to a large measure "tolerate" the rules of Native Law and Custom, its oppostion to the "customary" oath was well articulated. The most devastating argument against it was that it by-passes the law and to that extent it provided an alternative to the substantive rules of law. The validity of the "customary" oath has not been decided by the Courts in Nigeria because appeals that raise such issues are frequently argued before the appellate courts from a general evidentiary standpoint rather than from one which would raise teh validity of a "customary" oath in the context in which it is administered.

The present survey is meant to establish six propositions

(1) In Nigeria there are two system of Laws operating. The Native Law and Custom forming a series of sub-systems and the Nigerian legal system based upon English law principles and traditions, and modelled after English legal institutions.

(2) As a deliberate policy of the colonial regime the eclipsing of the sub-system has been organised through inter alia the "Repugnancy Clause". This was done through Section 19 of the Supreme Court Ordinance of 1863.

(3) The Native Law and Custom which forms the sub-system mirrors the trends, the mores and the beliefs that form the social infrastructure of a given tribe. To that extent the workings of the Native Courts that administer that law and the society over which it presides, remain in continuing harmony.

(4) The Nigerian Courts following the English legal traditions and the English procedures, are not totally equipped to respond to the demands of the Native Law and Custom, either for ideological and philosophical reasons or due to ethical and moral commitments.

(5) By failing to leave the two systems to evolve and grow independently and separartely of each other, the Nigerian legal system has to a large measure introduced a substantial degree of tension resulting in a non-representative judicial decision-making process.

(6) Had the two systems left to grow independently of each other then Nigeria could have produced a legal model similar to those that are found in former British Colonies in Asia; namely a legal mossaic ${ }^{76}$. Thatcould have made both the process for judicial decision making and the decisions produced out of it, more in tune with the society over which it presides than it has thus far been the case in Nigeria.

76 A Legal Mossaic results ourt of the co-existance of a number of legal systems almost side by with each other. India and Srilanka provides a classic example of such a formation. India recognises the existence of three legal systems functioning independently of each other. These are: The Hindu Law, the Muslim Law, and the Common Law of India. The latter was an adoption from the English Common Law. 
The Relationship between the Social-Structure and the Working of the Legal System: A Case Study on Access to Justice in Northern Nigeria

By M. L. MARASINGHE

The paper is intended to support the thesis that there exists a relationship between the social infra-structure of a given society and the workings of the legal system which presides over it. In an attempt to examine this relationship a Tribal legal system in the province of Katsina, in Northern Nigeria was chosen. Out of empirical research conducted in the Native or Tribal Courts in that region, a mass of 1500 decisions were collected and translated into English for use in this and other similar writings. Of this mass of 1500 cases, 300 cases have been chosen for use in this paper. These cases have been categorised into two broad categories. First, those concerned with the 'Customary' oaths and the second concerned with Divorce proceedings. These two areas have been singled out for the purposes of this paper for the reason that they both manifest strong cultural underpinnings peculiar to the societies to which they belong. The purpose of the paper is to show the extent to which the infra-structure of a given Tribal society and the workings of the legal system presiding over it maintains a distinct harmony, so that the social and/or Tribal manifestations are reflected to a very large measure in the decisions produced by the Native or Tribals Courts functioning in that society. At the concluding stages of this paper it is intended to show the extent to which the decisions made by the Nigerian Courts adjudicating outside the system of Native Law and Custom departs from the social and cultural underpinnings of the Native or Tribal societies in Nigeria.

\section{International Commodity Trade:}

A Scheme for Export Earnings Entitlements

By Leelananda De Silva

The stock ingredients of international commodity agreements - export quotas, production controls and buffer stocks - have not been effective instruments in supply management as they fail to exploit adequately the mutual interests which exist among commodity producing/exporting countries. The mutual interest of producing/exporting countries lies in the expansion of export earnings both for the commodity as a whole and for each individual country and a scheme to share these earnings through Export Earnings Entitlements could prove more flexible, realistic and effective. Export volume quotas, production controls and buffer stocks would be ancillary and supporting measures to achieve the primary objective of export earnings allocations. The central element of the scheme is to de-link, at least partially the present direct relationship between each country's volume of exports and its export earnings. An Export Earnings Entitlement Scheme should allocate earnings to each country not necessarily on the actual volumes it exports but on its Export Potential taking due regard of the principle that in an international commodity agreement both exports an the withholding of exports in the interests of supply management are contrubutions to the expansion of total export earnings. By concentrating attention on the distribution and allocation of cash rather than on quantities of commodities (export volumes quotas), it might be feasible by allocations of less or more cash to balance the costs and benefits accruing to each producing/exporting country within a commodity agreement. Imaginative formulation and operation of an Export Earnings Entitlement scheme might in time assist in the emergence of a 